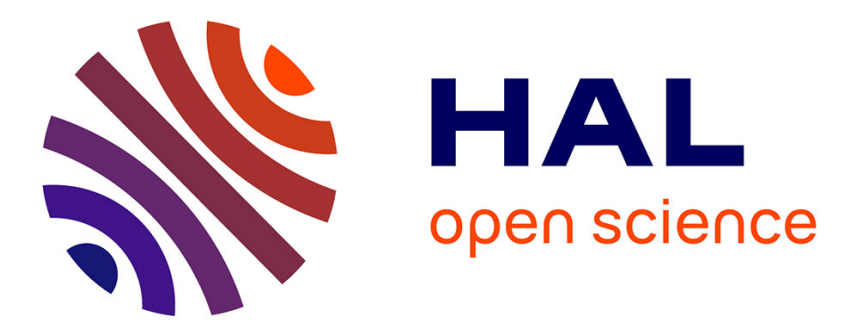

\title{
Contamination of raw milk with Bacillus cereus from farm to retail in Abidjan, Côte d'Ivoire and possible health implications
}

Bassa Yobouet, Sylvie Kouamé-Sina, Adjéhi Dadié, Kohei Makita, Delia Grace, Koffi Djè, Bassirou Bonfoh

\section{To cite this version:}

Bassa Yobouet, Sylvie Kouamé-Sina, Adjéhi Dadié, Kohei Makita, Delia Grace, et al.. Contamination of raw milk with Bacillus cereus from farm to retail in Abidjan, Côte d'Ivoire and possible health implications. Dairy Science \& Technology, 2013, 94 (1), pp.51-60. 10.1007/s13594-013-0140-7 . hal01234844

\author{
HAL Id: hal-01234844 \\ https://hal.science/hal-01234844
}

Submitted on 27 Nov 2015

HAL is a multi-disciplinary open access archive for the deposit and dissemination of scientific research documents, whether they are published or not. The documents may come from teaching and research institutions in France or abroad, or from public or private research centers.
L'archive ouverte pluridisciplinaire HAL, est destinée au dépôt et à la diffusion de documents scientifiques de niveau recherche, publiés ou non, émanant des établissements d'enseignement et de recherche français ou étrangers, des laboratoires publics ou privés. 


\title{
Contamination of raw milk with Bacillus cereus from farm to retail in Abidjan, Côte d'Ivoire and possible health implications
}

\author{
Bassa Antoine Yobouet • Sylvie Mireille Kouamé-Sina • \\ Adjéhi Dadié • Kohei Makita • Delia Grace • \\ Koffi Marcellin Djè • Bassirou Bonfoh
}

Received: 25 March 2013 / Revised: 29 May 2013 / Accepted: 30 May 2013 /

Published online: 27 June 2013

(C) INRA and Springer-Verlag France 2013

\begin{abstract}
In Africa, milk and dairy products play an important role in human nutrition but could represent a risk to human health, due to poor hygiene throughout the production chain. This study aimed firstly to assess the contamination of raw milk produced in traditional dairy farms in Abidjan with Bacillus cereus from farm to retail and secondly to assess the associated health risk for consumers in informal markets using a participatory approach. In total, 320 samples including 150 milk samples were collected in 15 purposively selected traditional dairy farms from four sites of Abidjan and analysed according to EN ISO 7932:2004 with slight modification. In addition, a survey was conducted in the three informal markets with 188 individuals who bought milk. B. cereus was found in $27 \%$ of the udder milk samples while $41 \%$ of the samples taken from seller's pooled milk contained B. cereus. Out of the 183 milk consumers, $14 \%$ reported daily consumption of unheated milk, indicating the high probability of exposure to B. cereus and other foodborne illnesses. After milk consumption, $13 \%$ of consumers reported that they contracted a foodborne illness. In conclusion, milk produced and sold in informal markets in Abidjan represents a risk
\end{abstract}

\footnotetext{
B. A. Yobouet $\cdot$ S. M. Kouamé-Sina $\cdot$ A. Dadié $\cdot$ K. M. Djè

Department of Food Science and Technology, Laboratory of Biotechnology and Food Microbiology, University of Nangui Abrogoua, 02 BP 801 Abidjan 02, Côte d'Ivoire
}

B. A. Yobouet $(\bowtie) \cdot$ S. M. Kouamé-Sina $\cdot$ B. Bonfoh

Environment and Health Department, Centre Suisse de Recherches Scientifiques en Côte d'Ivoire, 01 BP 1303 Abidjan 01, Côte d'Ivoire

e-mail: antoine.yobouet@csrs.ci

B. A. Yobouet

e-mail: bassaantoine2007@yahoo.fr

K. Makita $\cdot$ D. Grace

International Livestock Research Institute (ILRI), PO Box 30709, Nairobi, Kenya

K. Makita

Rakuno Gakuen University, 582 Bunkyodai Midorimachi, Ebetsu 069-8501, Japan 
for consumers' health and B. cereus is one possible cause. Milk quality could be improved by good hygiene practices, strengthening and targeting educational interventions and effective monitoring throughout the production and delivery chain.

Keywords Raw milk · Bacillus cereus $\cdot$ Risk $\cdot$ Health $\cdot$ Abidjan

\section{Introduction}

In Africa, milk and dairy products play an important role in human nutrition. Milk production is one of the most important livestock activities in West Africa and contributes to approximately $34 \%$ of the income of the milk producer (CSAO-OCDE/CEDEAO 2008). In Côte d'Ivoire, milk production fills only $10-18 \%$ of national demand for dairy products (BAD 2002). Approximately $92 \%$ of farmers are small scale (Youan-Bi 2008) and the majority of fresh milk is sold directly to consumers by farmers and small-scale traders in informal markets.

Most herders and milkers have little understanding of the hygiene and sanitary aspects of milk production. The practices of herders, milkers, collectors and sellers throughout the production chain do not adequately prevent or reduce contamination by pathogens capable of causing foodborne illnesses amongst consumers. Bacillus cereus, a common soil inhabitant, is one such pathogen. It is often present in milk and dairy products and considered an emerging opportunistic pathogen and an indicator of environmental contamination (Larsen and Jorgensen 1997). It is responsible for two different types of foodborne illnesses in humans, namely diarrhoeal and emetic forms, which are attributed to the bacteria's toxins (Rajkovic et al. 2008).

The impact of $B$. cereus on milk quality has never been studied in Abidjan, the largest city in Côte d'Ivoire. This study aimed at assessing the contamination of raw milk produced in traditional dairy farms in Abidjan with B. cereus, from the farm to retail, and to assess the risk for consumers in informal markets using a participatory approach. To achieve these objectives, (a) the milk production and marketing systems in Abidjan were characterised, (b) B. cereus isolates were identified at different stages of the production chain and (c) the risk to consumers was assessed through a survey relating to the consumption of raw milk and potential risk factors were identified.

\section{Materials and methods}

\subsection{Study area}

We conducted a cross-sectional study of the traditional dairy production system and informal marketing chain for raw milk in Abidjan. Four milk production sites were selected in peri-urban areas of Abidjan: Port-Bouët abattoir (four farms), Songon-té (one farm), Lièvre-rouge in Yopougon (two farms) and N'dotré Abobo (eight farms). Three of these four sites had informal raw milk markets and were selected for sampling pooled milk from sellers and for interviewing milk sellers: Port-Bouët abattoir (six sellers), Lièvre-rouge in Yopougon (two sellers) and Abobo-derrière rails (seven sellers). These sites were selected purposively, based on the population 
density, importance of the markets for the traditional dairy sector and the willingness of the actors (herdsmen, livestock owners, milk collectors and sellers) to participate in the study. The sites selected were estimated to incorporate $70 \%$ of traditional milk production chain in Abidjan.

\subsection{Milk and water samples}

Samples were collected on 17 occasions between October 2008 and September 2009, in the early morning after Muslim prayer time between 6:30 and 8:00 a.m. To identify the sources of contamination with $B$. cereus, different types of samples were aseptically collected before milking. Firstly, a pot containing $100 \mathrm{~mL}$ sterile distilled water was exposed to the open environment in an area where cows are milked for 15 min to assess environmental bacterial pollution. Secondly, the herder's milk containers were washed with $100 \mathrm{~mL}$ sterile distilled tap water and the recovered water was then collected in a sterile container to determine the contamination of the containers. Thirdly, swabs were collected from the skin of the udders of each cow milked. Fourthly, swabs from the hands of each milker were sampled. Fifthly, if farmers used a water storage container for water for household use, a volume of $100 \mathrm{~mL}$ of tap water from the household water storage container was collected in $150 \mathrm{~mL}$ sterile pots. To determine the points along the "farm to retail" chain at which contamination with $B$. cereus could occur, samples (100 mL aliquots) were collected aseptically in sterile $150 \mathrm{~mL}$ pots from the following three steps of milk production chain: (a) raw milk directly taken from all four teats of each cow after removal of the first jet of milk; (b) bulk milk from each farm, after brief mixing; and (c) pooled milk from sellers in informal markets. All samples examined are showed in Table 1. Immediately after collection, samples were chilled in an ice cooler box at $4{ }^{\circ} \mathrm{C}$ and transported to the laboratory of the Centre Suisse de Recherches Scientifiques en Côte d'Ivoire (CSRS) for analysis within $2 \mathrm{~h}$ after sampling.

\subsection{Isolation and identification of B. cereus}

In total, 320 samples including 150 milk samples were collected for the identification and quantification of $B$. cereus. Samples were decimal diluted according to standard NF V 08-010 (AFNOR 1996) and aliquots of $0.1 \mathrm{~mL}$ from appropriate dilutions were plated on sterile Mossel agar medium (Merck, Germany) according to the standard EN ISO 7932:2004 (European Standard EN ISO 7932 2004) with a slight modification. For this, haemolysis test on sheep blood agar was replaced by biochemical tests. Gram stain, motility, catalase production and fermentation of glucose anaerobically were determined. The number of $B$. cereus per millilitre was calculated according to the European Standard ISO 7218 (2007).

\subsection{Participatory risk assessment of the production chain of local raw milk}

Farmers were interviewed using a structured questionnaire in order to obtain information about the dairy production system, milk handling, hygiene and sanitary conditions of the farms.

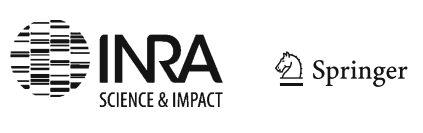


Table 1 Counts and prevalence of Bacillus cereus at critical milk handling points and in potential sources of contamination

\begin{tabular}{|c|c|c|c|c|c|}
\hline \multirow[t]{2}{*}{ Samples } & \multicolumn{3}{|c|}{ Count $\log \left(\mathrm{CFU} \cdot \mathrm{mL}^{-1}\right)$} & \multirow{2}{*}{$\begin{array}{l}\text { Number and percentage } \\
(\%) \text { of contaminated } \\
\text { samples by B. cereus }\end{array}$} & \multirow{2}{*}{$\begin{array}{l}\text { Number } \\
\text { of samples } \\
\text { examined }\end{array}$} \\
\hline & Minimum & Mean \pm SD & Maximum & & \\
\hline \multicolumn{6}{|l|}{ Critical points of contamination } \\
\hline Udder milk & 2.6 & $2.6 \pm 0.6$ & 4.1 & $32(27)$ & 119 \\
\hline Farm's bulk milk & 2.3 & $2.8 \pm 0.6$ & 3.7 & $4(29)$ & 14 \\
\hline Seller's pooled milk & 2.0 & $2.9 \pm 1.0$ & 4.5 & $7(41)$ & 17 \\
\hline Total & & & & $43(29)$ & 150 \\
\hline \multicolumn{6}{|l|}{ Sources of contamination } \\
\hline Udder skin & 1.0 & $2.2 \pm 0.6$ & 5.5 & $73(65)$ & 113 \\
\hline $\begin{array}{l}\text { Tap water from the household } \\
\text { water storage container }\end{array}$ & 2.1 & $2.6 \pm 0.7$ & 3.5 & $3(60)$ & 5 \\
\hline Environment (air) & 1.0 & $1.8 \pm 0.5$ & 2.5 & $8(53)$ & 15 \\
\hline Hand of milker & 1.5 & $2.3 \pm 0.4$ & 2.9 & $9(41)$ & 22 \\
\hline Farmer containers & 1.6 & $1.8 \pm 0.5$ & 2.1 & $4(33)$ & 15 \\
\hline Total & & & & & 170 \\
\hline
\end{tabular}

$S D$ standard deviation

An assessment of the impact of raw milk consumption on consumer health was conducted through consumer surveys. A total of 188 individuals who bought milk in the three informal markets were interviewed at the selling points. The questionnaire included questions relating to consumers' perceptions of the benefits of milk, consumption patterns, quantity and frequency of milk consumption and history and severity of illness following consumption of raw milk. Basic demographic information such as age, educational level and religion were also collected. The severity of adverse health effects due to milk consumption was determined by a scale ranging from 1 to 10, defined as follows: (1-3) mild illness, (4-8) severe illness and (9-10) very severe illness resulting in hospitalisation. Additionally, four focus group discussions were conducted in order to understand the practices and risk behaviours observed throughout the production chain and during milk consumption, such as knowledge of foodborne illness and factors influencing raw milk consumption. Each focus group included the livestock herders, the milkers, the livestock owners, the milk collectors, the milk sellers and the milk consumers.

\subsection{Statistical analysis}

All data were analysed with the statistical programme IBM SPSS version 19 (French version) for Windows (SPSS Inc., Chicago, USA). Descriptive statistics such as prevalence, mean and standard deviation were calculated for quantitative variables. Geometric and log-transformed means were used to calculate bacterial load. The least significant difference between the mean was determined. The relative risk (RR) of reported illness after milk consumption was calculated for various hypothesised risk factors. The mean probability of ingestion of raw milk contaminated by $B$. cereus at 
the level posing a risk to human health was calculated as the proportion of raw milk that had not undergone any heat treatment multiplied by the proportion of milk sales in excess of acceptable limits. These acceptable limits $\left(m=50\right.$ CFU.mL ${ }^{-1}, M=500$ CFU.mL ${ }^{-1}$, infectious dose $=10^{5}$ CFU. $\mathrm{mL}^{-1}$ ) were defined using a combination of different regulations described elsewhere (Clabots 2007; European 2007). The threshold for statistical significance was set at $p<0.05$.

\section{Results and discussion}

The milk production chain from farm to consumer in the informal sector in peri-urban areas of Abidjan is shown in Fig. 1. High humidity, mud and animal excrement were present in all milking areas. The milking environment for $94 \%$ farms was deemed to be unsafe. Before, during and after milking, the skin of the udder and the hands of the milkers were not cleaned or disinfected. Soap and disinfectant were also not used. Only one milker washed the utensils during all of the stages of milking. Calves usually suckled before milking. The milk was transported and distributed from farmers to sellers without cooling or heating. The unhygienic and unsanitary methods of milk production identified in the present study have also been described by several authors in Bamako, Mali (Bonfoh et al. 2003) and Niamey, Niger (Siousarran 2003). The practices identified could lead to contamination of raw milk on the farm with environmental $B$. cereus. Other sources of contamination are udder infections, addition of contaminated water and environmental contamination between farm and point of retail.

The average loads and the prevalence of $B$. cereus along the milk production chain from farmers to sellers are shown in Table 1 . Of the B. cereus positive (7/17) pooled milk samples from sellers, three (18\%) contained $B$. cereus from $1.7 \pm 0.5$ to $2.7 \pm 0.8$ $\log$ CFU.mL $\mathrm{mL}^{-1}$ and four (23\%) contained B. cereus from $2.7 \pm 0.8$ to $5.0 \pm 0.8 \log$ CFU.mL ${ }^{-1}$. In view of international standards, $18 \%$ of the pooled milk from sellers was classified to be of poor microbiological quality and $23 \%$ as very poor, posing a risk to human health. All of the contaminated pooled milk from sellers was above acceptable limits. B. cereus was found in $29 \%$ of the milk samples. Improper handling and temperature abuse between milking and retail would support growth of $B$. cereus. Indeed, the proportion of contaminated milk with B. cereus increased significantly from $27 \%$ to $41 \%$ from cows' udders to sellers' containers. Along the milk production chain, cows' udders and containers of herders and sellers are the critical points where the milk was contaminated by B. cereus. The udder skin, the tap water used by milker from household water container and the environment were the main sources of contamination (Table 1). The average load of B. cereus in the environment, on the udder skin and in the tap water used by milkers from household water container was $1.8 \pm 0.5,2.2 \pm 0.6$ and 2.6 $\pm 0.7 \log \mathrm{CFU}_{\mathrm{mL}}{ }^{-1}$, respectively. Milker's hands and utensils used for milking were secondary sources of contamination of milk by B. cereus, as prevalences were determined to be lower.

The consumer's survey is currently given in Table 2 . Only milk consumers were included in these calculations. The results showed that out of the 188 individuals who had bought milk at retail point, $183(97 \%)$ consumed milk, $59(32 \%)$ of these consumed milk daily and $112(61 \%)$ consumed milk 1 to 5 days/week. On average, 


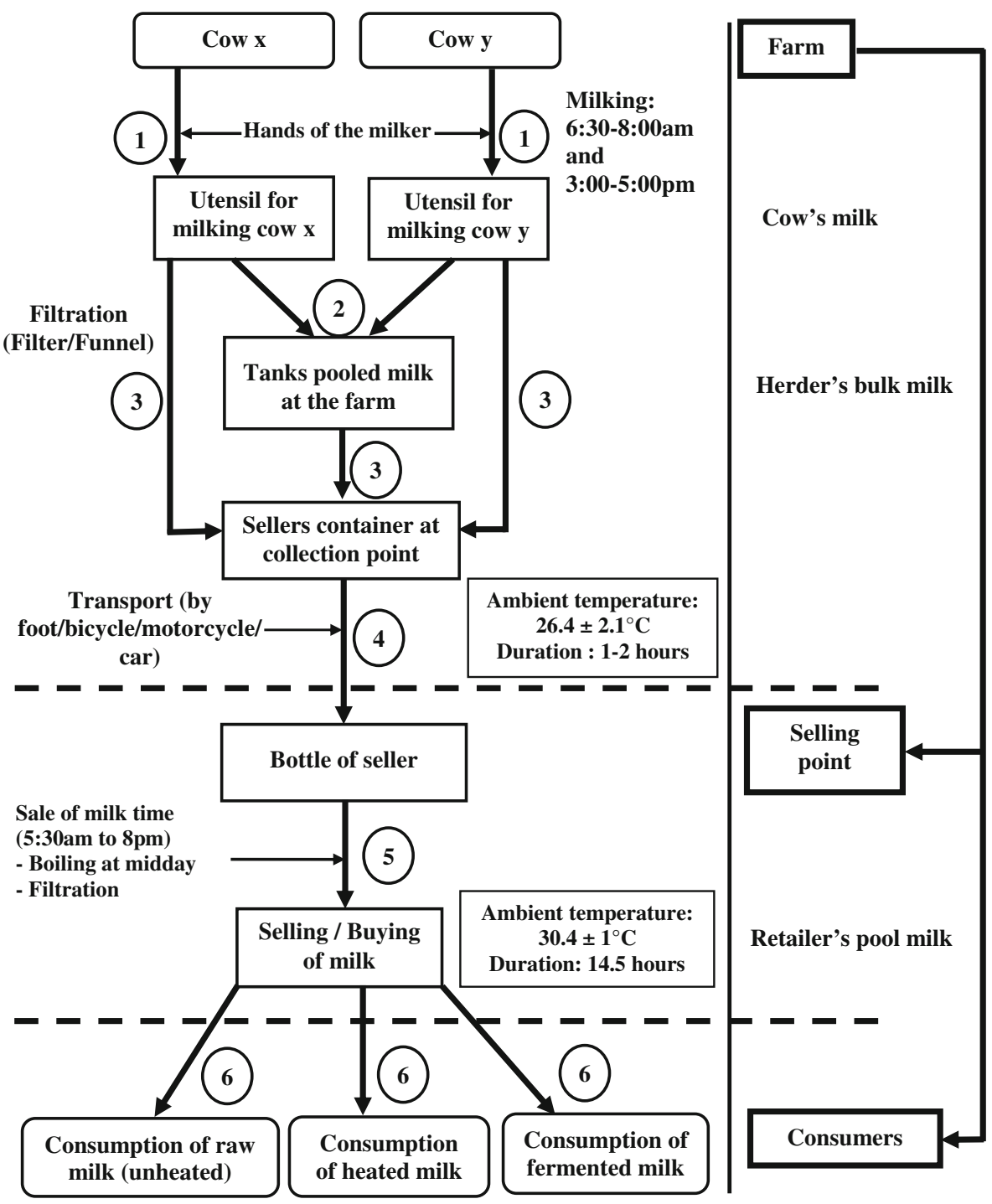

Fig. 1 The informal milk production chain from farm to consumer in Abidjan. (1) Milking, (2) filling the tank, (3) collection, (4) transport, (5) selling, (6) milk consumption trends

$0.44 \pm 0.6 \mathrm{~L}$ of milk was consumed per person each day. Overall, $52 \%(96 / 183)$ of the surveyed population consumed milk without any heat treatment. Nearly $14 \%$ $(25 / 183)$ of consumers consumed unheated milk daily. Focus group discussion revealed that producers, sellers and some consumers believed that raw milk was of better quality than boiled milk, and they preferred to drink raw milk. They believed that milk consumption did not ever cause illness. The raw milk produced in the study area was used for cultural rituals (68\%) and personal consumption (97\%). Rituals involved distributing raw milk with bread products as a gift to family members and neighbours, particularly children as recommended by Muslim tradition. The results are in line with previous reports, in which offering milk to children is a method of 
Table 2 Characteristics of milk customers and consumption behaviours

\begin{tabular}{lll}
\hline Characteristic & $\begin{array}{l}\text { Number of } \\
\text { customers } \\
(n=188)\end{array}$ \\
\hline
\end{tabular}

$\begin{array}{lll}\text { Sex of customers } & & \\ \text { Male } & 146 & 77.7 \\ \text { Female } & 42 & 22.3 \\ \text { Educational level of customers } & & \\ \text { No schooling } & 44 & 23.4 \\ \text { Primary school } & 30 & 16.0 \\ \text { Secondary school } & 24 & 12.8 \\ \text { University } & 8 & 4.3 \\ \text { Koranic school } & 52 & 27.7 \\ \text { No Koranic school } & 13 & 6.9 \\ \text { Primary Koranic school } & 13 & 6.4 \\ \text { Secondary Koranic school } & 5 & 2.7 \\ \text { Religion of customers/consumers } & & \\ \text { Christian } & 6 & 3.2 \\ \text { Muslim } & 181 & 96.3 \\ \text { Others } & 1 & 0.5\end{array}$

Age of customers/consumers

$\begin{array}{lll}\leq 18 \text { years } & 8 & 4.4 \\ 19-49 \text { years } & 139 & 76.0 \\ 50-59 \text { years } & 19 & 10.4 \\ \geq 60 \text { years } & 11 & 6.0 \\ \text { Not determined } & 6 & 3.3\end{array}$

Milk consumption patterns

Consumption of milk

$\begin{array}{lll}\text { No } & 5 & 3 \\ \text { Yes } & 183 & 97 \\ \text {-Heated milk } & 87 & 47 \\ \text {-Unheated milk } & 96 & 52 \\ \quad \text { Daily consumption of } & 25 & 14 \\ \text { unheated milk } & & \\ \begin{array}{l}\text { requency of milk consumption } \\ \text { Occasionally (least 1 day }\end{array} & 3 & 2 \\ \text { every 2 months) } & \\ \text { One to 2 days/month } & 9 & 5 \\ \text { One to 5 days/week } & 112 & 61 \\ \text { Daily } & 59 & 32\end{array}$

purification because children are considered to be pure and holy (Fokou et al. 2010). Indeed, the study population considered raw milk as a natural product because it had been modified in any way. Thus, the high frequency of consumption of unheated milk (at least among consumers surveyed), sociocultural factors and consumers' mis-perception of milk quality (not boiling milk, milk cannot cause illness) could 
Table 3 Health implications linked to milk consumption among 183 consumers in informal markets in Abidjan, Côte d'Ivoire

\begin{tabular}{lll}
\hline Parameters & Number & Percentage \\
& of milk & \\
& consumers \\
& $(n=183)$ & \\
& \\
\hline
\end{tabular}

$\begin{array}{lll}\text { Health implication linked to milk consumption } & \\ \text { Diseases } & 23 & 13 \\ \text { No diseases } & 160 & 87 \\ \text { Symptoms reported to be linked to milk consumption }(n=23) \\ \text { Diarrhoea } & 18 & 54 \\ \text { Stomach pains } & 7 & 21 \\ \text { Fever } & 4 & 12 \\ \text { Vomiting and nausea } & 3 & 9 \\ \text { Cough } & 1 & 3 \\ \text { Total } & 33 \text { cases } & 100.0\end{array}$

Onset of symptoms links to milk consumption (h)

$\begin{array}{lll}20 & 8 & 35 \\ 24 & 9 & 39 \\ 36 & 6 & 26\end{array}$

Duration of symptoms (h)

$\begin{array}{lll}\text { Less than } 24 & 5 & 22 \\ \text { More than } 24-48 & 12 & 52 \\ >48 & 6 & 26\end{array}$

Severity of diseases

Mild illness (continues working) $\quad 12 \quad 52$

Severe illness (stay at home) $\quad 8 \quad 35$

Very severe illness (stay in hospital) $3 \quad 13$

contribute to an overall increased risk, particularly to children is a risk factor for milkborne disease.

By multiplying the proportion of raw milk that had not undergone any heat treatment $(52 \%)$ with the proportion of seller's milk samples over acceptable limits (41\%), it was estimated that the probability of consuming milk contaminated by B. cereus at the level posing a risk to human health was $21 \%$. No one reported being ill after milk consumption at the time of interview, but symptoms potentially associated with food poisoning due to the consumption of milk were reported by milk consumers. In our study, symptoms potentially associated with food poisoning linked to the consumption of milk were reported by $13 \%(23 / 183)$ of milk consumers and most of these symptoms (74\%) occurred less than $24 \mathrm{~h}$ after milk consumption (Table 3). The occurrence of selfreported gastrointestinal illness was significantly related to the consumption of unheated local milk $(\mathrm{RR}=2.9 ; 95 \% \mathrm{CI}=1.1-7.7, p=0.025)$. The fraction of risk attributable to the consumption of unheated milk was $61 \%$ and the attributable risk was $11 \%$. Symptoms most often mentioned were diarrhoea (54\%) and stomach pains (21\%; Table 3). Of these illnesses, $13 \%$ were very severe requiring a stay for 1 to 3 days in a hospital. These results are similar to the findings of other studies (Dierick et al. 2005; Dromigny 2008; Oliver et al. 2009) which reported abdominal pain, cramps and diarrhoea as the main 
symptoms of the diarrhoeal syndromes. Sometimes, illnesses reported due to B. cereus can be severe, requiring hospitalisation and even sometimes resulting in death (Dierick et al. 2005; Dromigny 2008).

\section{Conclusion}

This study is to our knowledge the first reported assessment of B. cereus in the traditional milk value chain in Abidjan. Milk was shown to be heavily contaminated by $B$. cereus throughout the production chain from the farm to retail point. It is likely that milk produced and sold in informal markets in Abidjan presents a risk for consumers' health and B. cereus is one possible cause. Therefore, steps should be taken to improve milk quality including systems for monitoring milk quality and providing incentives for meeting quality standards are recommended. However, as milk and dairy products provide important contributions to livelihoods and nutrition, precaution is needed to ensure that measures taken to improve quality do not jeopardize these benefits. This study contributes to the understanding of the contamination of raw milk in Abidjan by $B$. cereus and the possible health implications.

Acknowledgments The present study was conducted under the Safe Food Fair Food project of the International Livestock Research Institute and funded jointly by the German Federal Ministry of International Cooperation (GIZ), the Programme d'Appui Stratégique à la Recherche Scientifique en Côte d'Ivoire, the Centre Suisse de Recherches Scientifiques en Côte d'Ivoire, the Federal Commission for Scholarships for Foreign Students of the Swiss Confederation (ref. 2010.0197/Ivory Coast/OP) and by ETH Zürich through the laboratory of food biotechnology. We sincerely thank all partners. The management team and laboratory staff at the CSRS and all participating farmers are gratefully acknowledged. Finally, we thank Professor Christophe Lacroix and Professor Leo Meile who kindly welcomed the primary author in the Laboratory of Food Biotechnology at the ETH and Ms. Kristina Rosel, Dr. Solenne Costard and Dr. Anna Dean for their support during the drafting of this manuscript

Conflict of interest There is no conflict of interest concerning this manuscript.

\section{References}

AFNOR (1996) Norm NF V 08-010. In: Microbiologie des aliments - Règles générales pour la préparation des dilutions en vue de l'examen. Analyse microbiologique recueil de normes françaises. 6ème Ed. Paris, pp 67-75. [Food microbiology-general rules for preparation of dilutions for the analysis. Microbiological analysis compendium of French standards]

BAD (2002) Projet de Développement de l'Elevage phase II. Evaluation à mi-parcours, Rapport définitif. BDPA, Abidjan, Côte d'Ivoire, pp 215. [Proposed livestock development phase II. Mid-term review, final report]

Bonfoh B, Wasem A, Traoré AN, Fané A, Spillmann H, Simbé CF, Alfaroukh IO, Nicolet J, Farah Z, Zinsstag J (2003) Microbiological quality of cows' milk taken at different intervals from the udder to selling point in Bamako (Mali). Food Control 14:495-500

Clabots (2007) Critères microbiologiques des denrées alimentaires, lignes directrices pour l'interprétation. Luxembourg. F-054 Rev01, pp 30. [Microbiological Criteria for Foodstuffs, guidelines for interpretation]. http://www.securite-alimentaire.public.lu/

CSAO-OCDE/CEDEAO (2008) Elevage et marché régional au sahel et en Afrique de l'ouest. Potentialités et défis. Edn Club du Sahel et de 1'Afrique de l'ouest/OCEDE. 182 p. [Livestock and regional market for the Sahel and West Africa. Opportunities and challenges] 
Dierick K, Van Coillie E, Swiecicka I, Meyfroidt G, Devlieger H, Meulemans A, Hoedemaekers G, Fourie L, Heyndrickx M, Mahillon J (2005) Fatal family outbreak of Bacillus cereus-associated food poisoning. J Clin Microbiol 43(8):4277-4279

Dromigny E (2008) Bacillus cereus. Monographies de microbiologie, Edn Tec \& Doc, Lavoisier, Paris [Monographs of Microbiology]

European Standard EN ISO 7932 (2004) Microbiology of food and animal feeding stuffs - Horizontal method for the enumeration of presumptive Bacillus cereus - Colony-count technique at $30^{\circ} \mathrm{C}$ (ISO 7932:2004). $24 \mathrm{pp}$

European Standard ISO 7218 (2007) Microbiology of food and animal feeding stuffs_-general requirements and guidance for microbiological examinations. $66 \mathrm{pp}$

European Union (2007) Commission Regulation (EC) no. of 5 December 2007 amending Regulation (EC) No. 2073/2005 on microbiological criteria for foodstuffs. Official Journal of the European Union of 07.12.2007. L 322/12-L322/29

Fokou G, Koné BV, Bonfoh B (2010) Mon lait est pur et ne peut pas rendre malade: motivations des acteurs du secteur informel et qualité du lait local au Mali. Rev. Afr. Santé et Prod. Anim. 8(S): 75-86. [My milk is pure cannot make someone sick: informal sector stakeholders' motivations and quality of local milk in Mali]

Larsen HD, Jorgensen K (1997) The occurrence of Bacillus cereus in Danish pasteurized milk. Int J Food Microbiol 34:179-186

Oliver SP, Boor KJ, Murphy SC, Murinda SE (2009) Food safety hazards associated with consumption of raw milk. Foodborne Pathog Dis 6(7):793-806

Rajkovic A, Uyttendaele M, Dierick K, Samapundo S, Botteldoorn N, Mahillon J, Heyndrickx M (2008) Risk profile of the Bacillus cereus group implicated in food poisoning. Report for the Superior Health Council Belgium. CSS-HGR 8316 public health implications of Bacillus cereus in food. $80 \mathrm{pp}$

Siousarran V (2003) Hygiène du lait cru en zone urbaine et périurbaine de Niamey, Niger. Rapport de stage. CIRAD-EMVT; Université Montpellier II, pp 65. [Hygiene of raw milk in urban and peri-urban of Niamey, Niger]

Youan-Bi A (2008) Efficacité managériale des éleveurs de bovins en Côte d'Ivoire : cas des départements de Toumodi et de Korhogo, Thèse Unique de doctorat de l'Université de Cocody, UFR Sciences Economiques et de Gestion, 170 pp, Soutenue le 28 juin 2008, Abidjan. [Managerial efficiency of cattle in Côte d'Ivoire: case of departments of Toumodi and Korhogo] 